\title{
SINTESIS HIDROKSIAPATIT BERUKURAN NANO DENGAN METODE ELEKTROKIMIA DIBANTU EDTA
}

\author{
Adrian Nur, Desi Liah Martasari, Desy Nurwijayanti, Samsudin Affandi, \\ Arief Widjaja, Heru Setyawan* \\ Jurusan Teknik Kimia, Fakultas Teknologi Industri \\ Institut Teknologi Sepuluh Nopember \\ Kampus ITS, Sukolilo, Surabaya 60111 \\ Email: sheru@chem-eng.its.ac.id
}

\begin{abstract}
Abstrak
Penelitian tentang sintesis hidroksiapatit berukuran nano dengan metode elektrokimia telah dilakukan. Penelitian ini bertujuan mempelajari pengaruh kondisi operasi terhadap pembentukan partikel hidroksiapatit.Elektrosintesis dilakukan dengan menggunakan larutan $\mathrm{Ca}^{2+} / \mathrm{EDTA} / \mathrm{PO}_{4}{ }^{3-} 0,25 / 0,25 / 0,15 \mathrm{M}$. Ada dua perlakuan sebelum penyaringan yaitu langsung disaring dan dibiarkan dulu selama 3 hari pada $40{ }^{\circ} \mathrm{C}$ (proses penuaan). Endapan yang dihasilkan kemudian disaring dan dicuci dengan air demin untuk menghilangkan pengotor dan sisa reaktan yang tidak bereaksi. Endapan dikeringkan dengan suhu $40{ }^{\circ} \mathrm{C}$ selama 2 hari untuk selanjutnya dikarakterisasi. Hasil menunjukkan bahwa dengan metode elektrokimia bisa dihasilkan partikel hidroksiapatit berukuran nano. Partikel yang dihasilkan berbentuk jarum atau plat dengan diameter BET 19-143 nm. Diameter partikel yang dihasilkan berbanding terbalik dengan kenaikan rapat arus, waktu elektrolisa dan konsentrasi EDTA. Sebaliknya, diameter partikel berbanding lurus dengan jarak elektrode dan suhu. Selain itu jenis partikel yang dihasilkan sangat bergantung pada $\mathrm{pH}$ akhir dari proses elektrolisis maupun perlakuan penuaan, dimana $\mathrm{pH}>8$ cenderung membentuk HA, sedangkan $\mathrm{pH}<8$ cenderung membentuk fasa brushit.
\end{abstract}

Kata kunci:hidroksiapatit, nanopartikel, elektrokimia, sintesis, karakterisasi

\begin{abstract}
EDTA-ASSISTED SYNTHESIS OF NANOSIZED HYDROXYAPATITE BY ELECTROCHEMICAL METHOD. Synthesis of nanosized hydroxyapatite by electrochemical method has been studied. The aim of this work is to study the effects of variuos parameters on hydroxyapatite particles. The electrochemical synthesis was prepared in solution $\mathrm{Ca}^{2+} / \mathrm{EDTA}^{2} / \mathrm{PO}_{4}{ }^{3}$ at concentration $0.25 / 0.25 / 0.15 \mathrm{M}$. The solution was electrolized by using constant direct current at certain current density. There were two treatments for particles after electrosynthesized, namely without aging or aged for 3 days at $40{ }^{\circ} \mathrm{C}$. For both cases, the particles were filtered and washed by demineralized water to eliminate the impurities and unreacted reactans. Then, the particles were dryed at $40{ }^{\circ} \mathrm{C}$ for 2 days. The dryed particles were characterized by X-Ray diffraction, surface area analyzer, scanning electron microscopy, Fourier transform infrared spectra and thermogravitimetric and differential thermal analysis. The results showed that nanosized hydroxyapatite were produced by electrochemical method. The produced particles were composed of needle-like or plate-like morphologies with equivalent diameter 19-143 $\mathrm{nm}$. The produced particles diameters were inversely proportional to current density, duration of electroysis and EDTA concentration, and proportional to the distance between two electrodes and temperature. The product calcium phosphates types depended on the final $\mathrm{pH}$ of electrolysis process and aging treatment. It would tend to hydroxyapatite if $\mathrm{pH}>8$ and brushite if $\mathrm{pH}<8$.
\end{abstract}

Keywords: hydroxyapatite, nanoparticle, electrochemical, synthesis, characterize

*penulis korespondensi 


\section{PENDAHULUAN}

Biokeramik kalsium ortofosfat telah digunakan pada ilmu kedokteran gigi, ortopedik, dan ilmu bedah selama lebih dari 30 tahun. Faktor pendorong penggunaan kalsium ortofosfat termasuk hidroksiapatit (HA) sebagai bahan pengganti tulang adalah kemiripan komposisi kimianya dengan komponen bahan tulang dan gigi manusia, sehingga bersifat tidak beracun, biokompatibel, tidak dianggap sebagai bahan asing oleh tubuh, dan bersifat bioaktif serta terpadu dalam jaringan hidup dengan proses aktif yang sama seperti dalam tulang sehat (Dorozhkin, 2010a). Lima puluh persen tulang dibentuk oleh modifikasi HA yang menempatkan HA sebagai mineral utama tulang. Implan HA berpori digunakan sebagai pengantar obat lokal pada tulang. Selain pada tulang, HA juga merupakan mineral utama pada enamel gigi. Aplikasi dan prospek penggunaan HA berukuran nano untuk perbaikan tulang dan gigi rusak memiliki potensi yang sangat menjanjikan (Dorozhkin, 2010b). Material nano mempunyai luas permukaan yang lebih besar daripada material konvensional ukuran mikrometer. Nanokristal HA dapat digunakan dalam semen tulang dengan sinterabilitas, densifikasi, dan bioaktivitas yang lebih baik dibandingkan kristal ukuran besar. HA berukuran nano dapat meningkatkan kemampuan mineralisasi sel secara in vivo dan dapat terserap pada lapisan email secara lebih kuat. Dengan demikian, HA berukuran nano berpotensi untuk merevolusi teknik implan jaringan keras, yaitu perbaikan tulang dan gigi, serta untuk sistem penghantaran obat.

Berbagai metode telah dikembangkan untuk mensintesis nanopartikel HA yang meliputi metode presipitasi (Li dkk., 2007; Cengiz dkk., 2008), hidrotermal (Xin dkk., 2010; Zhang dkk., 2011), mekano-kimiawi (Nasiri-Tabrizi dkk., 2009), flame spray (Loher dkk., 2005), dan deposisi elektrokimia (Wang dkk., 2005;Lu dkk., 2005;Blackwood dan Seah, 2009). Di antara metode-metode di atas, elektrokimia menawarkan metode yang mudah dan sederhana. Dengan metode ini ukuran partikel dapat dengan mudah dikendalikan dengan mengatur tegangan atau arus (Fajaroh dkk., 2011) terutama jika dibandingkan dengan metode presipitasi, yang walaupun lebih sederhana namun mempunyai kesulitan dalam mengendalikan ukuran partikel. Metode elektrokimia juga menggunakan energi yang jauh lebih rendah karena dilakukan pada suhu rendah (bandingkan dengan metode hidrotermal) dan tanpa perlakuan mekanikal seperti pada metode mekano-kimiawi.

Proses sintesis HA secara elektrokimia dibantu dengan EDTA (ethylenadiaminetetraacetic acid), yang berfungsi sebagai pengendali konsentrasi $\mathrm{Ca}^{2+}$ dalam larutan melalui reaksi kesetimbangan berikut:

$\mathrm{Ca}^{2+}+\mathrm{EDTA}^{4-} \rightarrow \mathrm{Ca}\left(\mathrm{EDTA}^{2+}\right.$

Konsentrasi $\mathrm{Ca}^{2+}$ perlu dikendalikan untuk menghindari presipitasi cepat karena bereaksi dengan $\mathrm{PO}_{4}{ }^{3-}$ membentuk kalsium fosfat.

Dengan metode elektrokimia, Djosic, dkk. mendapatkan bahwa ukuran kristalit tidak dipengaruhi oleh $\mathrm{pH}$ dan rapat arus (Djošić dkk., 2008). Ukuran partikel yang dihasilkan relatif besar dan memiliki rentang partikel yang lebar. Hasil ini diperoleh dari pengujian dengan $\mathrm{pH}$ larutan dan rapat arus yang relatif tinggi. Secara teoritik, peningkatan $\mathrm{pH}$ dan rapat arus akan mempercepat reaksi pembentukan partikel dan mendorong terjadinya agglomerasi partikel. Jika $\mathrm{pH}$ dan rapat arus relatif tinggi, maka ukuran partikel tidak lagi dipengaruhi $\mathrm{pH}$ dan rapat arus, tetapi lebih oleh kuantitas reaktan yang tersedia dan waktu sintesis. Pada rapat arus yang relatif rendah, kedua parameter itu mungkin berpengaruh. Oleh karena itu, perlu dipelajari pengaruh kedua parameter tersebut pada rentang dimana arus tidak membatasi reaksi, atau dengan kata lain, transfer muatan relatif rendah sehingga difusi dan migrasi ion memiliki peran yang cukup. Penelitian ini bertujuan untuk mempelajari pengaruh kondisi operasi dalam rentang dimana transfer muatan dan difusi memiliki peran dalam menentukan kecepatan reaksi terhadap pembentukan partikel hidroksiapatit.

\section{METODE}

Sintesis nanopartikel hidroksiapatit dengan metode elektrokimia pada penelitian ini dilakukan dengan dengan menggunakan arus searah konstan. Larutan elektrolit dibuat dengan mencampur $\mathrm{Na}_{2} \mathrm{H}_{2}$ EDTA. $2 \mathrm{H}_{2} \mathrm{O}$, $\mathrm{KH}_{2} \mathrm{PO}_{4}$ dan $\mathrm{CaCl}_{2}$ pada konsentrasi $\mathrm{Ca}^{2+} /$ EDTA/PO ${ }_{4}^{3-} 0,25 / 0,25 / 0,15 \mathrm{M}$ dengan volume total $200 \mathrm{~mL}$ jika tidak dinyatakan lain. Nilai $\mathrm{pH}$ awal larutan diatur dengan variasi dari 3,5 sampai 4 dengan 
menambahkan larutan $\mathrm{NaOH}$. Elektroda anoda dan katoda berupa plat karbon berukuran $52 \mathrm{~mm} \times 20 \mathrm{~mm} \times 5 \mathrm{~mm}$. Kedua elektroda dihubungkan dengan catu daya searah (GW Instek GPD X303S). Selanjutnya, presipitat yang dihasilkan diproses dengan penuaan pada suhu $40{ }^{\circ} \mathrm{C}$ selama 3 hari (pengecualian pada beberapa percobaan tidak melalui proses penuaan yang akan disebutkan), dipisahkan antara larutan dan presipitatnya dengan menggunakan kertas saring, dicuci dengan air rendah mineral, dan dikeringkan pada $40{ }^{\circ} \mathrm{C}$ selama 2 hari. dilakukan dalam gelas kimia $250 \mathrm{~mL}$ yang dimasukkan pada waterbath (Gambar 1). Rapat arus divariasi dari $26-53 \mathrm{~mA} / \mathrm{cm}^{2}$, waktu elektrolisis 3-9 jam, suhu 20-60 ${ }^{\circ} \mathrm{C}$, jarak elektroda 1-5 cm, dan konsentrasi EDTA 0,1-0,4 M.

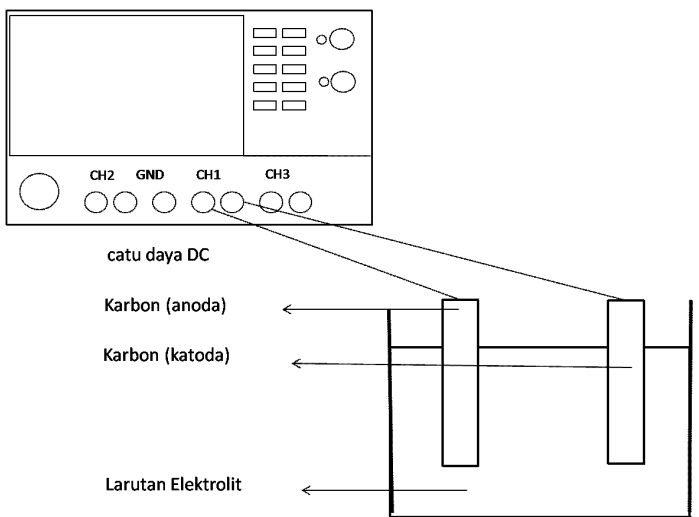

Gambar 1. Rangkaian alat sintesis elektrokimia

Karakteristik produk hidroksiapatit yang diamati antara lain adalah struktur kristal dan partikel penyusun dengan uji XRD, diameter ekivalen partikel yang diukur dengan metode BET, morfologi produk dengan metode uji SEM, identifikasi gugus fungsi dengan uji FTIR dan stabilitas termal dengan metode uji TG-DTA.

Penentuan diameter rata-rata partikel dilakukan dengan metode umum penentuan diameter partikel berdasarkan pengukuran luas permukaan spesifik. Metode ini menggunakan asumsi bahwa seluruh partikel berbentuk bola (sphere) dan tidak berpori dengan persamaan (2).

$$
\operatorname{diameter}(D)=\frac{6}{\rho \times a_{s}}
$$

$\rho$ adalah densitas partikel dan $a_{s}$ adalah luas permukaan spesifik.

\section{HASIL DAN PEMBAHASAN}

Hidroksiapatit telah berhasil disintesis dengan metode elektrokimia sederhana menggunakan arus searah konstan berupa serbuk berwarna putih yang halus. Analisis XRD mengidentifikasi serbuk berwarna putih tersebut sebagai fasa hidroksiapatit (HA) (Gambar 2) dengan diperolehnya puncakpuncak yang bersesuaian dengan pola difraksi standar HA dengan rumus kimia $\mathrm{Ca}_{10}\left(\mathrm{PO}_{4}\right)_{6}(\mathrm{OH})_{2}$, (JCPDS 03-0747). Namun, pada pola XRD tersebut juga dapat terlihat bahwa metode arus searah konstan pada berbagai variasi rapat arus dengan $\mathrm{pH}$ awal 4 menghasilkan produk berupa fasa kalsium ortofosfat lain yang ditunjukkan oleh adanya puncak-puncak yang bersesuaian dengan difraksi standar brushit (B) dengan rumus kimia $\mathrm{CaHPO}_{4} .2 \mathrm{H}_{2} \mathrm{O}$, (AMCSD 0008884).

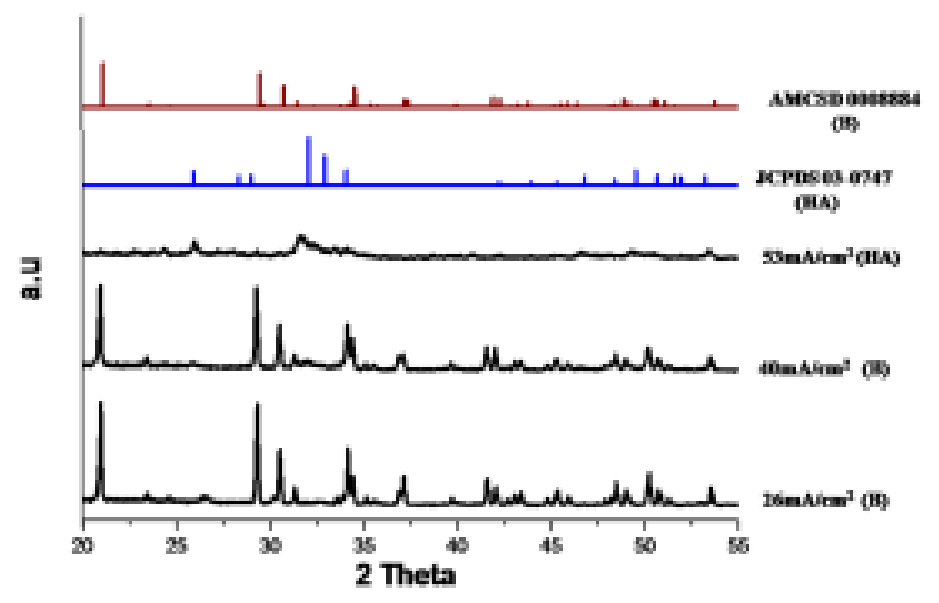

Gambar 2. Pola XRD hydroxyapatite hasil sintesis pada variasi rapat arus (waktu sintesis 9 jam tanpa penuaan) 
Selanjutnya, pengaruh variabel waktu elektrolisis, suhu, dan jarak elektroda diperlihatkan pada Gambar 3, 4, dan 5. Proses pembentukan sangat dipengaruhi oleh konsentrasi ion-ion elektrolit yang terlibat seperti $\mathrm{Ca}^{2+}, \mathrm{PO}_{4}{ }^{3+}$ dan $\mathrm{OH}^{-}$. Konsentrasi $\mathrm{Ca}^{2+}$ dikendalikan oleh kesetimbangan Ca-EDTA dan konsentrasi $\mathrm{PO}_{4}{ }^{3+}$ dikendalikan oleh kesetimbangan asam fosfat dalam larutan. Konsentrasi $\mathrm{OH}^{-}$dipengaruhi oleh hasil elektrolisis air yang menghasilkan $\mathrm{OH}^{-}$. Karena konsentrasi $\mathrm{Ca}^{2+}$ dan $\mathrm{PO}_{4}{ }^{3-}$ telah terkendali, akibatnya $\mathrm{pH}$ larutan memegang peranan penting terhadap pembentukan partikel. Waktu elektrolisis, suhu larutan, jarak elektroda, dan arus yang digunakan akan mempengaruhi $\mathrm{pH}$ larutan akhir yang diperoleh, yang selanjutnya mempengaruhi proses pembentukan partikel. Gambar 3, 4, dan 5 menunjukkan bahwa pembentukan HA didorong oleh semakin panjangnya waktu elektrolisis, semakin tingginya suhu, dan semakin dekatnya jarak elektroda. Pada rapat arus yang rendah, waktu elektrolisis pendek, suhu rendah, dan jarak elektroda yang jauh mula-mula akan terbentuk brushit. Brushit ini kemudian berubah menjadi hidroksiapatit dengan meningkatkan rapat arus, waktu elektrolisis, dan suhu elektrolisis serta dengan mendekatkan jarak elektorda.

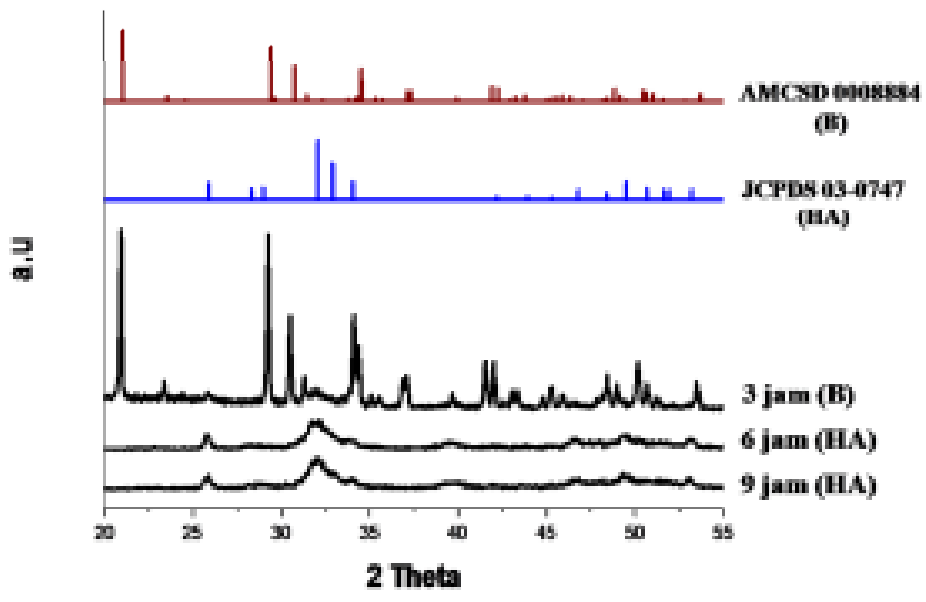

Gambar 3. Pola XRD Hydroxyapatitehasil sintesis pada variasi waktu elektrolisis (rapat arus $53 \mathrm{~mA} / \mathrm{cm}^{2}$ tanpa aging)

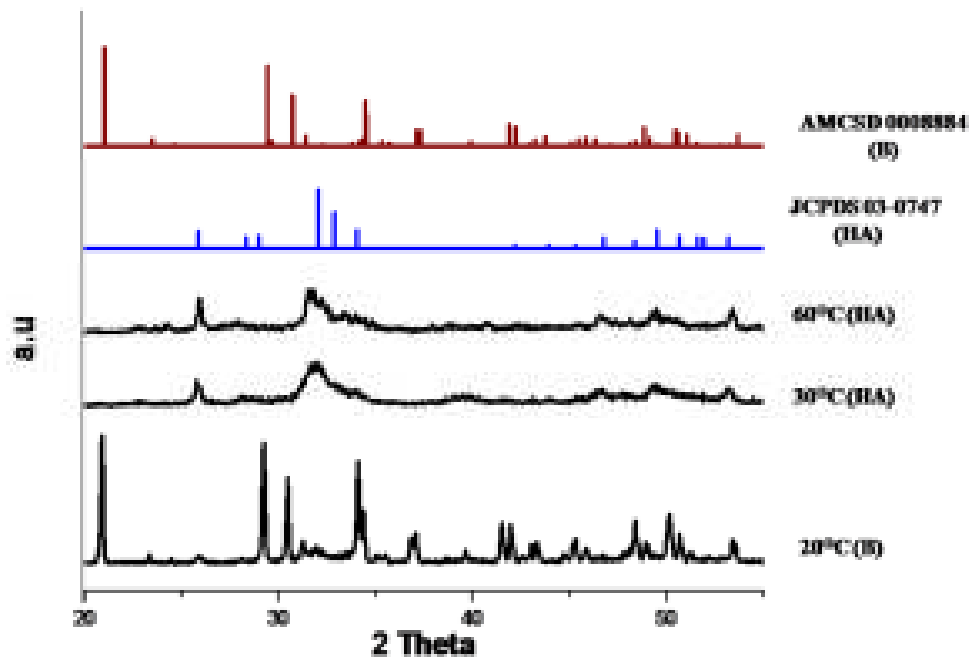

Gambar 4. Pola XRD Hydroxyapatitehasil sintesis pada variasi suhu elektrolisis (rapat arus $53 \mathrm{~mA} / \mathrm{cm}^{2} 6$ jam tanpa aging) 


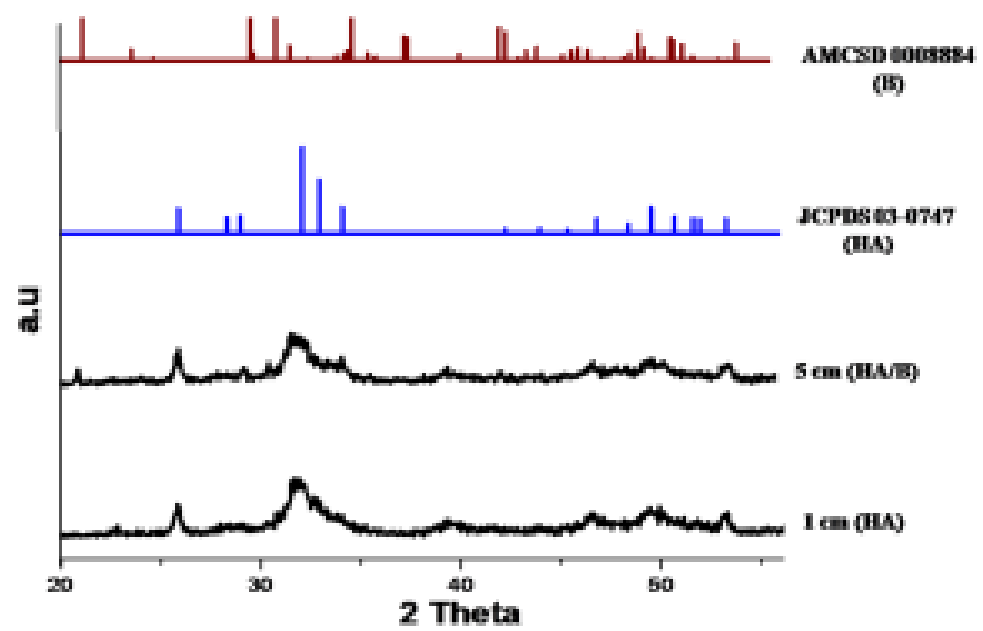

Gambar 5. Pola XRD Hydroxyapatitehasil sintesis pada variasi jarak elektroda (rapat arus 53 $\mathrm{mA} / \mathrm{cm}^{2} 6$ jam tanpa aging)

Diperolehnya fasa HA sangat dipengaruhi oleh $\mathrm{pH}$ akhir elektrolisis dan perlakuan penuaan setelah proses elektrolisis yang dapat dilihat pada Tabel 1. Semakin besar rapat arus (i) yang diberikan, semakin cepat larutan elektrolit mencapai $\mathrm{pH}$ tinggi. Pada Tabel 1 HA cenderung terbentuk pada $\mathrm{pH}$ akhir lebih besar dari 8. Pada $\mathrm{pH}<8$, partikel cenderung membentuk fasa brushit (B). Pada variabel suhu (T), kenaikan suhu mempercepat reaksi reduksi air membentuk $\mathrm{OH}^{-}$sehingga $\mathrm{pH}>8$ lebih cepat tercapai. Untuk variabel waktu elektrolisis (t), waktu mempengaruhi $\mathrm{pH}$ akhir reaksi dimana semakin lama waktu maka $\mathrm{pH}$ akan semakin meningkat. Variasi jarak elektroda (d) menunjukkan bahwa dengan memperkecil jarak elektroda maka akan meningkatkan $\mathrm{pH}$ akhir karena semakin kecilnya hambatan antar elektroda sehingga reaksi elektrolisa semakin mudah. Penuaan terhadap produk sintesis juga cukup berpengaruh, yaitu semakin cenderung membentuk HA.

Untuk mengetahui macam-macam gugus fungsi yang terdapat pada hidroksiapatit, maka dilakukan analisis FTIR pada bilangan gelombang 4000-500 cm-1 (Gambar 6). Spektra infra merah menunjukkan ciri khas ikatan fasa hidroksiapatit, yang ditunjukkan oleh ikatan stretching gugus $-\mathrm{OH}$ pada bilangan gelombang $3564 \mathrm{~cm}^{-1}$. Bilangan gelombang 960, 472, 1049, dan $599 \mathrm{~cm}^{-1}$ mencirikan vibrasi dari gugus fungsi $\mathrm{PO}_{4}^{3-}$ Bilangan gelombang $555 \mathrm{~cm}^{-1}$ pada kisaran ini adalah gugus milik $\mathrm{PO}_{4}{ }^{3}$. Hasil dari FTIR ini semakin menguatkan hasil analisis XRD bahwa pada rapat arus $>40 \mathrm{~mA} / \mathrm{cm}^{2}$ dengan lama sintesis 6 jam menghasilkan partikel hydroxyapatite $\mathrm{Ca}_{10}\left(\mathrm{PO}_{4}\right)_{6}(\mathrm{OH})_{2}$ yang ditandai dengan adanya stretching ikatan $\mathrm{OH}$, vibrasi $\mathrm{PO}_{4}{ }^{3-}$ dan gugus fungsi $\mathrm{PO}_{4}{ }^{3-}$.

Tabel 1. Variasi Kondisi Proses dengan Fasa Kalsium Ortofosfat yang Dihasilkan

\begin{tabular}{|c|c|c|c|c|c|c|c|}
\hline \multirow{2}{*}{$\begin{array}{c}\mathrm{pH} \\
\text { Awal }\end{array}$} & \multicolumn{4}{|c|}{ Kondisi } & \multirow{2}{*}{$\begin{array}{c}\text { pH } \\
\text { akhir }\end{array}$} & \multirow{2}{*}{$\begin{array}{l}\text { Aging } \\
3 \text { hari }\end{array}$} & \multirow[t]{2}{*}{ Jenis } \\
\hline & $\begin{array}{c}\mathrm{i} \\
\left(\mathrm{mA} / \mathrm{cm}^{2}\right)\end{array}$ & $\begin{array}{c}\mathrm{t} \\
\text { (jam) }\end{array}$ & $\begin{array}{c}\mathrm{T} \\
\left({ }^{\circ} \mathrm{C}\right)\end{array}$ & $\begin{array}{c}d \\
(\mathrm{~cm})\end{array}$ & & & \\
\hline 4,5 & 26,27 & 3 & 30 & 3 & 5 & $\mathrm{~V}$ & B \\
\hline 4,5 & 53,33 & 3 & 30 & 3 & 6 & V & HA \\
\hline 3,5 & 53,33 & 6 & 30 & 3 & 8 & V & HA \\
\hline 3,5 & 53,33 & 9 & 30 & 3 & 9 & V & HA \\
\hline 4 & 53,33 & 6 & 60 & 3 & 9 & X & HA \\
\hline 4 & 53,33 & 6 & 20 & 3 & 6 & X & B \\
\hline 4 & 53,33 & 6 & 30 & 1 & 8,5 & X & HA \\
\hline 4 & 53,33 & 6 & 30 & 5 & 8 & X & $\mathrm{HA} / \mathrm{B}$ \\
\hline
\end{tabular}




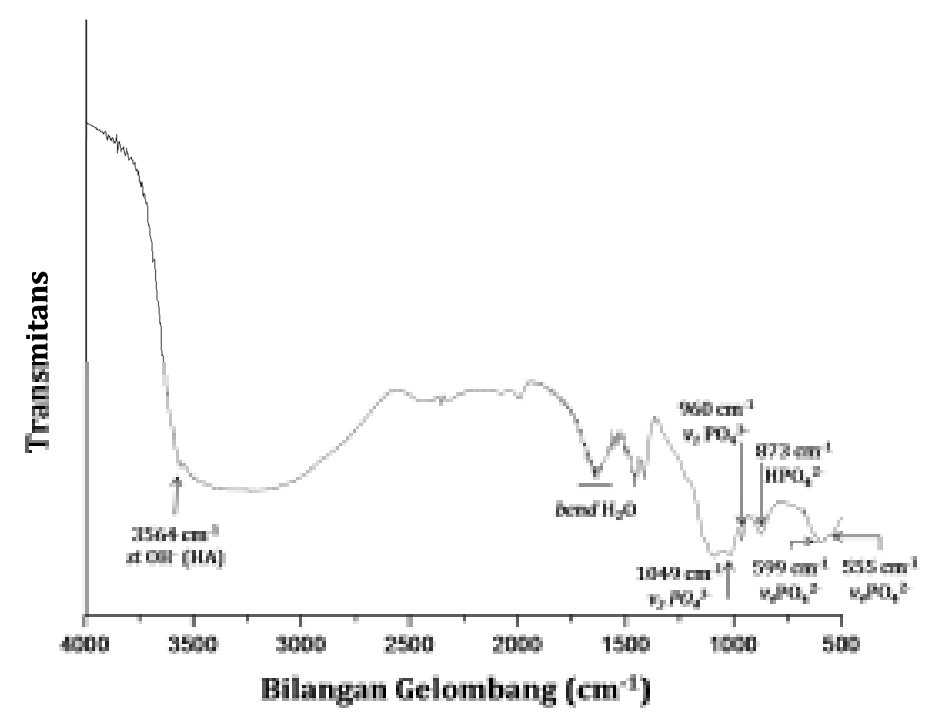

Gambar 6. Spektrum infra merah HA pada variabel jarak elektroda $3 \mathrm{~cm}$, lama sintesis 6 jam, rapat arus $53 \mathrm{~mA} / \mathrm{cm}^{2}$, pada suhu kamar dengan melibatkan penuaan

Untuk mengetahui stabilitas thermal partikel HA maka dilakukan uji TG/DTA. Gambar 7 menunjukkan hasil uji TG/DTA untuk sampel yang disintesis pada $53 \mathrm{~mA} / \mathrm{cm}^{2}$ dengan jarak antar elektroda $3 \mathrm{~cm}$ pada suhu kamar selama 3 jam dengan penuaan. Dua kurva pada Gambar 7 masing-masing menggambarkan pola perubahan massa sampel akibat pemanasan serta pola aliran panas yang menyertainya. Penurunan massa sampel terjadi secara bertahap, penurunan massa sampel terjadi pada suhu $100{ }^{\circ} \mathrm{C}$, pada suhu ini terjadi desorpsi air akibat pemanasan. Penurunan massa sampel berikutnya terjadi pada suhu sekitar 200-300 ${ }^{\circ} \mathrm{C}$ disebabkan oleh oksidasi material organik seperti EDTA.
Penurunan massa sampel yang ketiga terjadi pada suhu sekitar $850^{\circ} \mathrm{C}$ akibat dehidroksilasi HA dan transformasi menjadi oksihidroksiapatit.

Selanjutnya, dilakukan pencitraan produk dengan SEM untuk mengetahui ukuran dan morfologi partikel hidroksiapatit yang dihasilkan, yang diperlihatkan pada Gambar 8. Terlihat bahwa partikel berbentuk mirip jarum pada permukaan untuk penuaan, dan mirip plat pada kondisi tanpa penuaan. Namun, pada pencitraan SEM tersebut partikel masih terlihat saling tumpang tindih, sehingga diamater rata-rata partikel dicari dengan pendekatan diameter ekivalen melalui pengukuran luas permukaan spesifik (surface

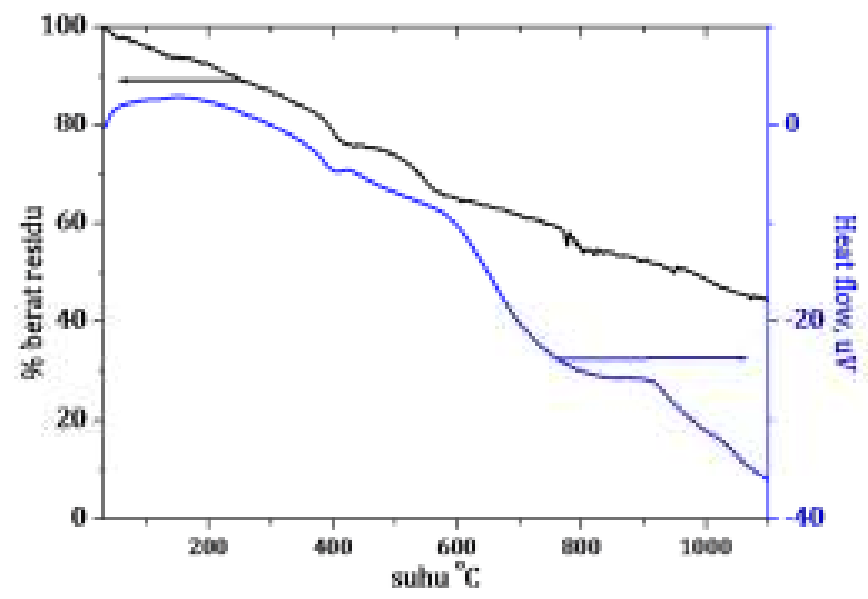

Gambar 7. Hasil analisis TG/DTA HA hasil sintesis pada $53 \mathrm{~mA} / \mathrm{cm}^{2}$, jarak antar elektroda $3 \mathrm{~cm}$, suhu kamar selama 3 jam dengan penuaan 
area) melalui metode Brunauer-Emmett-Teller analysis (BET) sehingga didapat diameter ekivalen rata-rata. Gambar 9 menunjukkan hubungan diameter partikel dengan berbagai variabel yang digunakan.
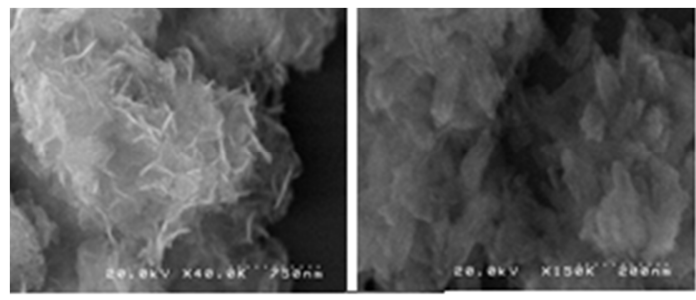

Gambar 8. Citra SEM hidroksiapatit yang dihasilkan dengan kondisi sintesis 53 $\mathrm{mA} / \mathrm{cm}^{2}$; 6 jam; $2 \mathrm{~cm}$; EDTA 0,25 M; $30{ }^{\circ} \mathrm{C}$; dengan penuaan (kiri) dan tanpa penuaan(kanan)

Gambar 9 (a) menunjukkan bahwa semakin lama waktu elektrolisis maka diameter rata-rata ekivalen partikel cenderung akan semakin kecil, dengan perlakuan penuaan memiliki diameter partikel yang lebih kecil daripada perlakuan tanpa penuaan. Hal ini diduga dipengaruhi oleh proses tumbukan antar partikel yang mengakibatkan pemecahan, sehingga semakin lama waktu elektrolisis semakin banyak partikel yang tumbuh dan frekuensi tumbukan antar partikel semakin tinggi. Hasil penuaan memperlihatkan diameter yang lebih kecil daripada tanpa penuaan pada kondisi yang sama. Proses penuaan memberikan kesempatan partikel untuk lebih menata posisi. Selain itu, analisis SEM pada Gambar 8 memperlihatkan perbedaan permukaan dari perlakuan penuaan dan tanpa penuaan yang kemungkinan menyebabkan terjadinya perubahan luas permukaan.

Gambar 9 (b) menunjukkan bahwa semakin besar rapat arus yang diberikan, diameter partikel hidroksiapatit semakin kecil. Salah satu komponen ion yang signifikan dalam pembentukan hidroksiapatitadalah banyaknya keberadaan ion $\mathrm{OH}^{-}$. Besarnya rapat arus yang diberikan akan mempercepat pelepasan elektron dimana elektron-elektron ini yang selanjutnya akan berperan pada reaksi reduksi air di katoda yang menghasilkan $\mathrm{OH}^{-}$. Banyaknya $\mathrm{OH}^{-}$mem-percepat pembentukan inti partikel HA namun mengurangi ruang partikel untuk tumbuh sehingga diameternya semakin kecil.

Gambar 9 (c) menunjukkan bahwa semakin tinggi suhu pada proses elektrolisis, diameter partikel cenderung semakin besar. Meskipun demikian, perbedaan ukurannya tidak terlalu signifikan.

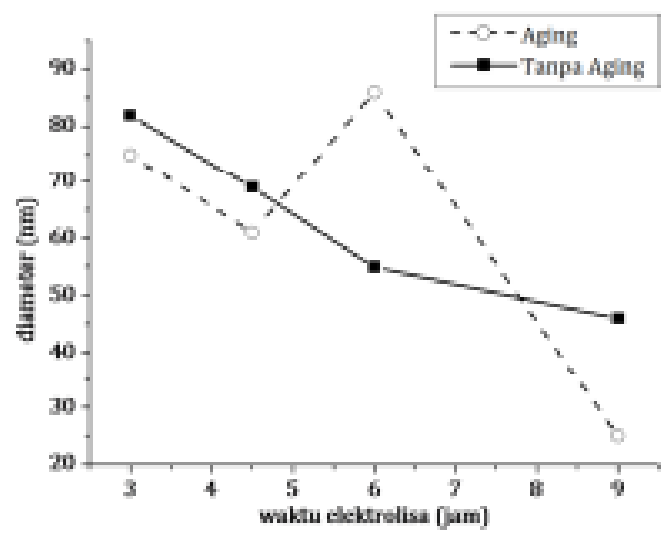

(a) Variasi waktu elektrolisis $53 \mathrm{~mA} / \mathrm{cm}^{2}, 3 \mathrm{~cm}$, 30, EDTA 0,25.

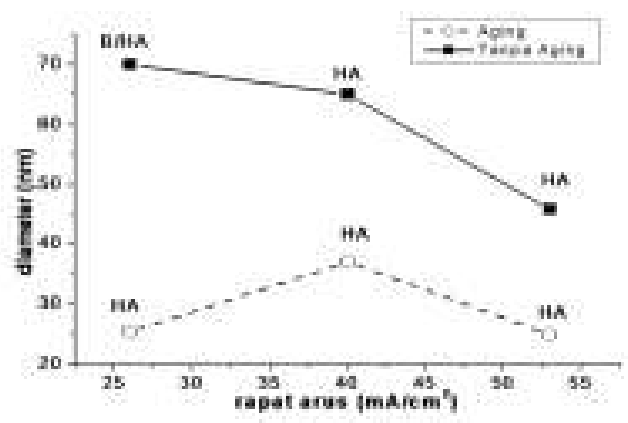

(b) Variasi rapat arus $9 \mathrm{Jam}, 3 \mathrm{~cm}, 30^{\circ} \mathrm{C}$, EDTA $0,25 \mathrm{M}$

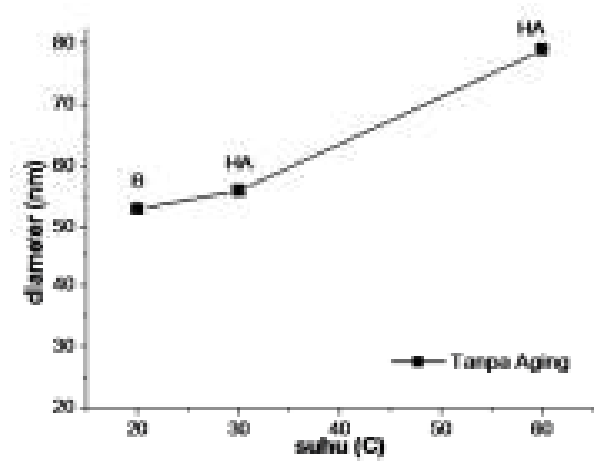

(c) Variasi suhu elektrolisis $53 \mathrm{~mA} / \mathrm{cm}^{2}, 6 \mathrm{Jam}$, $3 \mathrm{~cm}$, EDTA 0,25 M

Gambar 9 (d) menunjukkan bahwa semakin kecil jarak elektroda, maka diameter rata-rata ekivalen partikel cenderung akan semakin kecil. Hal ini karena kondisi cenderung pada pembentukan inti partikel yang lebih cepat daripada proses pertumbuhan partikel. Gambar 9 (e) menunjukkan bahwa semakin besar 
konsentrasi EDTA akan berkecenderungan membentuk ukuran partikel yang semakin kecil. Hal ini karena EDTA memiliki fungsi mengikat $\mathrm{Ca}^{2+}$ sebagai prekursor pembentuk HA, sehingga HA terbentuk perlahan. Pada konsentrasi EDTA 0,4 M, hidroksiapatit tidak terbentuk.

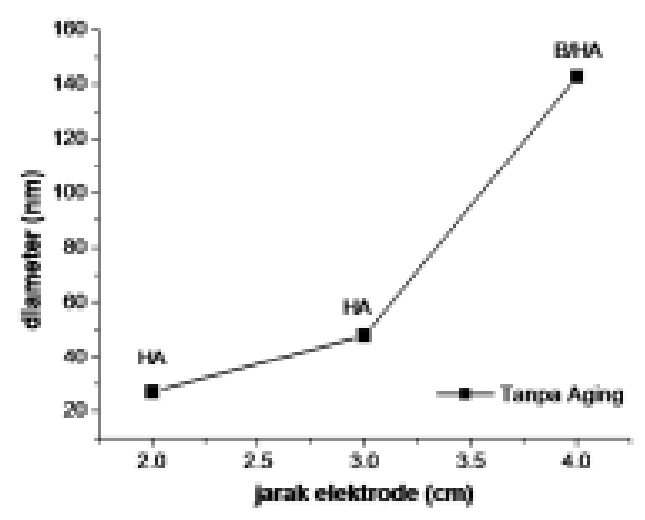

(d) Variasi jarak elektroda $53 \mathrm{~mA} / \mathrm{cm}^{2}, 6 \mathrm{Jam}$, $30{ }^{\circ} \mathrm{C}$, EDTA 0,25 M

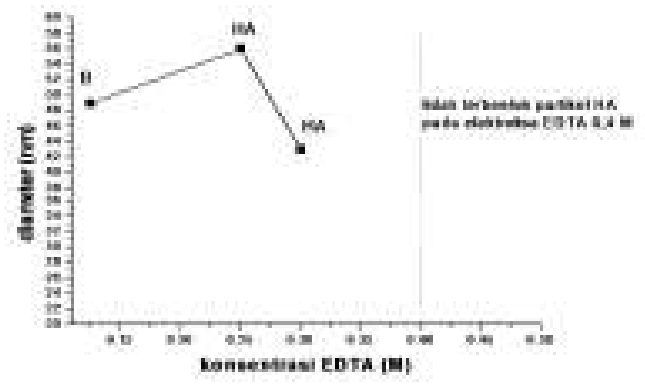

(e) Variasi konsentrasi EDTA $53 \mathrm{~mA} / \mathrm{cm}^{2}, 6 \mathrm{Jam}$, $30{ }^{\circ} \mathrm{C}, 3 \mathrm{~cm}$

\section{Gambar 9. Diameter ekivalen partikel pada berbagai variasi kondisi operasi}

\section{KESIMPULAN}

Nanopartikel hidroksiapatit dengan kemurnian tinggi telah berhasil disintesis secara elektrokimia dengan arus searah konstan. Nanopartikel hidroksiapatit yang dihasilkan berbentuk jarum atau plat berdiameter ekivalen 19-143 nm, dimana diameter partikel cenderung semakin kecil dengan semakin besarnya variabel rapat arus, waktu elektrolisis dan konsentrasi EDTA. Sebaliknya, semakin besar jarak elektroda dan semakin tinggi suhu, semakin besar diameter partikel. Hidroksiapatit yang dihasilkan bersifat stabil terhadap suhu hingga $850{ }^{\circ} \mathrm{C}$ dan berubah menjadi oksihidroksiapatit jika pemanasan melebihi suhu $850^{\circ} \mathrm{C}$.
Jenis calcium phosphate yang dihasilkan sangat bergantung pada $\mathrm{pH}$ akhir dari proses elektrolisis maupun perlakuan penuaan. Ketika pH akhir lebih besar 8, fasa yang terbentuk adalah hidroksiapatit, dan ketika pH akhir kurang dari 8, fasa yang terbentuk adalah brushit.

\section{UCAPAN TERIMA KASIH}

Penelitian ini dibiayai oleh Hibah Penelitian Non Unggulan ITS. Salah satu penulis (A. N.) berterimakasih kepada Direktorat Jendral Pendidikan Tinggi, Kementerian Pendidikan dan Kebudayaan Indonesia melalui Program PHKI UNS.

\section{DAFTAR PUSTAKA}

Blackwood, D. J.; Seah, K. H. W., Electrochemical cathodic deposition of hydroxyapatite: improvements in adhesion and crystallinity, Materials Science and Engineering: C, 2009, 29(4), 1233-1238.

Cengiz, B.; Gokce, Y.; Yildiz, N.; Aktas, Z.; Calimi, A., Synthesis and characterization of hydroxyapatie nanoparticle, Colloids and Surfaces A: Physicochemical and Engineering Aspects, 2008, 322(1), 29-33.

Dorozhkin, S. V., Bioceramics of calcium orthophosphates, Biomaterials, 2010a, 31(7), 1465-1485.

Dorozhkin, S. V., Nanosized and nanocrystalline calcium orthophosphates, Acta Biomaterialia, 2010b, 6(3), 715-734.

Djošić, M. S.; Mišković-Stanković, V. B.; Milonjić, S.; Kačarević-Popović, Z. M.; Bibić, N.; Stojanović, J., Electrochemical synthesis and characterization of hydroxyapatite powders, Materials Chemistry and Physics, 2008, 111(1), 137-142.

Fajaroh, F.; Setyawan, H.; Widyastuti, W.; Winardi, S., Synthesis of magnetite nanoparticles by surfactant-free electrochemical method in an aqueous system, Advanced Powder Technology, 2011, 23, 328-333.

Li, Y.; Wiliana, T.; Tam, K. C., Synthesis of amorphous calcium phosphate using various types of cyclodextrins, Materials Research Bulletin, 2007, 42(5), 820-827. 
Loher S.; Stark, W. J.; Maciejewski M.; Baiker A.; Pratsinis S.; Reichardt D.; Maspero, F.; Krumeich, F.; Günther D., Fluoro-apatite and calcium phosphate nanoparticles by flame synthesis, Chemistry of Materials, 2005, 17(1), 36-42.

Lu, X.; Zhao, Z.; Leng, Y., Calcium phosphate crystal growth under controlled atmosphere in electrochemical deposition, Journal of crystal growth, 2005, 284(3), 506-516.

Nasiri-Tabrizi, B.; Honarmandi, P.; EbrahimiKahrizsangi, R.; Honarmandi, P., Synthesis of nanosize single-crystal hydroxyapatite via mechanochemical method, Materials Letters, 2009, 63(5), 543-546.
Wang, S. H.; Shih, W. J.; Li, W. L.; Hon, M. H.; Wang, M. C., Morphology of calcium phosphate coatings deposited on a Ti-6Al-4V substrate by an electrolytic method under 80Torr, Journal of the European Ceramic Society, 2005, 25(14), 3287-3292.

Xin, R.; Ren, F.; Leng, Y., Synthesis and characterization of nano-crystalline calcium phosphates with EDTA-assisted hydrothermal method, Materials and Design, 2010, 31(4), 1691-1694.

Zhang, G.; Chen, J.; Yang, S.; Yu, Q.; Wang, Z.; Zhang, Q., Preparation of amino-acidregulated hydroxyapatite particles by hydrothermal method, Materials Letters, 2011, 65(3), 572-574. 